10 - REVIEW

\title{
Animal models of obesity in rodents. An integrative review ${ }^{1}$
}

\author{
Melina Ribeiro Fernandes $\mathbf{I}$, Nayara Vieira de Lima ${ }^{\mathrm{I}}$, Karoline Silva Rezende ${ }^{\mathrm{I}}$, Isabela Caroline Marques Santos ${ }^{\mathrm{I}}$, Iandara \\ Schettert Silva ${ }^{I I}$, Rita de Cássia Avellaneda Guimarães ${ }^{\text {III }}$
}

DOI: http://dx.doi.org/10.1590/S0102-865020160120000010

Trabalho apresentado no XV Congresso Internacional de Cirurgia Experimental-SOBRADPEC e II Fórum de Pós-Graduação em Ciências da Saúde da Região Centro-Oeste, Campo Grande-MS. 23 a 26 de novembro/2016.

\section{ABSTRACT}

PURPOSE: To perform an integrative review of the main animal disease models in rodents used for obesity.

METHODS: Research was conducted in the CAPES Portal database using the following keywords "obesity animal models, diet and rodents", published between the years 2010 to 2016 . We found 108 articles, of which 19 were selected and analyzed in full for this study. RESULTS: Larger part of publications occurred in the last 6 years, the rats $(n=10)$ were used in the same proportion mice $(n=10)$. The choice of male animals $(n=18)$ and age greater than 21 days $(n=17)$ showed a major highlight. The greater than 5 week follow-up period ( $\mathrm{n}=18$ ) was the most applied. A High Fat Diet was the most used in studies $(\mathrm{n}=18)$.

CONCLUSIONS: Male rodents continue to be considered the species most used in experimental studies to induce obesity, also was found variations of age to the beginning of the experiment. For the most part are follow-up time studies along with the use of High Fat Diet.

Key words: Obesity. Animal Experimentation. Diet. Rodentia. 


\section{Introduction}

In the last years, the obesity has reached epidemic proportions globally. It is considered a public health problem in the worldwide ${ }^{1}$. Overweight is an important risk factor for chronic non-communicable diseases (CNCDs) such as diabetes mellitus, hypertension, cardio vascular disease and cancer. It is caused by several factors, such as genetic predisposition, inadequate eating habits and sedentary lifestyle ${ }^{2}$.

According to the World Health Organization (WHO) obesity can be understood as a grievance of multivariate origin and is result of positive energy balance that favors the accumulation of fat, related to risks to health due to its relationship to metabolic complications such as hypertension, hypercholesterolemia, hypertriglyceridemia and diabetes ${ }^{3}$.

In some studies of action mechanisms in obesity that induce physiological disorders is used animal model in research environment. In this context, it is mainly used rodents which have the ability to develop obesity through genetic changes or by consumption of a palatable and high calorie diet. Thus, the animal model develops the disease more similar way to the genesis of obesity in humans.

To study the action mechanisms present in obesity that inducing physiological disorders, can be used animal model in research environment. In this context, it is used mainly rodents, who develop obesity through genetic changes.

The laboratory rat due to the physiological, anatomical and metabolic similarity with the human, has been used as an animal model for the study of many diseases. Scientists have also started to create mice as model because they have interesting phenotypes. Mice are considered excellent for the study of genetic therefore have a relatively short cycle and are genetically similar to humans as well as easy to handle 5 .

Thus, the aim of the present study is to perform an integrative review of the major animal disease models in rodents used for obesity.

\section{Methods}

In this review were included experimental studies that use animal models of disease to obesity. Were considered studies published in scientific journals between the years 2010-2016, in Portuguese, English or Spanish. Exclusion criteria were: (1) studies that did not include the eligibility criteria described above; (2) Systematic reviews; (3) Case study; (4) Case study; (5) Retrospective studies and (6) Observational Studies;

The searches for experimental studies were conducted by CAPES Portal database. The survey was conducted from March to July 2016 with the DeCS / MeSH descriptors: Obesity; animal Models; Diet; Rodents.

For extracting data were first evaluated the titles and abstracts of all articles identified by the search strategy. All abstracts that did not provide enough information on the inclusion and exclusion criteria were selected to read in full. In the second stage, were assessed the full papers to select those in accordance with the eligibility criteria.

The extraction of data was accomplished through standardized forms that included: article title, author and year of publication; animals used (species, sample number, age and sex); study design, rating scale, the study duration; type diet and results of intervention If there was any inconsistency in the analysis, the original documents were recovered and investigated again. The outcomes of interest were: lineage; age; sex; tracking time and type of diet. Data were analyzed using descriptive statistics.

\section{Results}

In this work, 108 articles were found from the electronic search in the database. Of these, 19 articles were included in this review, according to the selection criteria described in the methodology. Table 1 contains the selected articles for review in accordance with the outcomes used for this study. The main data found in these works were shown in Table 2. 
TABLE 1 - Selected articles according to the type, age and sex of animals, follow-up time and type of diet used between the years 2010-2016 $(\mathrm{n}=19)$.

\begin{tabular}{|c|c|c|c|c|c|}
\hline $\begin{array}{l}\text { AU- } \\
\text { TORS }\end{array}$ & $\begin{array}{l}\text { TYPE OF } \\
\text { ANIMAL }\end{array}$ & AGE & SEX & $\begin{array}{l}\text { FOLLOW- } \\
\text {-UP TIME }\end{array}$ & $\begin{array}{c}\text { TYPE } \\
\text { OF DIET }\end{array}$ \\
\hline $\begin{array}{l}\text { Privi- } \\
\text { tera }^{10}\end{array}$ & Rats SD & $\begin{array}{c}21 \\
\text { days }\end{array}$ & Male & 13 weeks & $\begin{array}{c}\text { High Fat } \\
60 \%\end{array}$ \\
\hline $\begin{array}{l}\text { Wata- } \\
\text { nabe }^{11}\end{array}$ & $\begin{array}{c}\text { Mice } \\
\text { C57BL }\end{array}$ & $\begin{array}{c}6 \text { a } 7 \\
\text { weeks }\end{array}$ & Male & 96 days & $\begin{array}{c}\text { High Fat } \\
60 \%\end{array}$ \\
\hline $\begin{array}{l}\text { Calli- } \\
\text { garis }^{12}\end{array}$ & $\begin{array}{c}\text { Mice } \\
\text { C57BL }\end{array}$ & $\begin{array}{c}5 \\
\text { weeks }\end{array}$ & Male & $\begin{array}{c}16 \\
\text { months }\end{array}$ & $\begin{array}{c}\text { High Fat } \\
60 \%\end{array}$ \\
\hline Krüger $^{13}$ & $\begin{array}{c}\text { Mice } \\
\text { C57BL }\end{array}$ & $\begin{array}{c}10-12 \\
\text { weeks }\end{array}$ & Male & 10 weeks & High Fat \\
\hline $\begin{array}{l}\text { Walews- } \\
\qquad \mathrm{ki}^{14}\end{array}$ & $\begin{array}{l}\text { Rats } \\
\text { wistar } \\
\text { Mice } \\
\text { C57BL }\end{array}$ & $\begin{array}{c}18 \\
\text { weeks }\end{array}$ & Female & 20 weeks & $\begin{array}{c}\text { High Fat } \\
60 \%\end{array}$ \\
\hline
\end{tabular}

\begin{tabular}{|c|c|c|c|c|c|}
\hline $\begin{array}{l}\text { Boren- } \\
\text { gasse }^{15}\end{array}$ & Rats SD & $\begin{array}{c}60 \\
\text { days }\end{array}$ & $\begin{array}{c}\text { Male } \\
\text { and } \\
\text { Female }\end{array}$ & 12 weeks & $\begin{array}{c}\text { High } \\
\text { Carb72\%, } \\
\text { High Fat } \\
40-45 \%\end{array}$ \\
\hline Lalanza $^{16}$ & Rats SD & $\begin{array}{c}21 \\
\text { days }\end{array}$ & $\begin{array}{c}\text { Male } \\
\text { and } \\
\text { Female }\end{array}$ & 8 weeks & Cafeteria \\
\hline Shao $^{17}$ & $\begin{array}{c}\text { Mice } \\
\text { C57BL }\end{array}$ & $\begin{array}{c}8 \\
\text { weeks }\end{array}$ & Male & 12 weeks & $\begin{array}{c}\text { High Fat } \\
40 \%\end{array}$ \\
\hline Tillman $^{18}$ & $\begin{array}{c}\text { Mice } \\
\text { C57BL }\end{array}$ & ND & Male & 14 weeks & $\begin{array}{c}\text { High } \\
\text { Carb, } \\
\text { High Fat } \\
45 \% ; 67 \%\end{array}$ \\
\hline Guan $^{1}$ & Rats SD & ND & Male & 90 days & $\begin{array}{l}\text { High Fat, } \\
\text { High Carb }\end{array}$ \\
\hline $\begin{array}{l}\text { Mc pher- } \\
\text { son }^{2}\end{array}$ & $\begin{array}{c}\text { Mice } \\
\text { C57BL }\end{array}$ & $\begin{array}{c}5 \\
\text { weeks }\end{array}$ & Male & 9 weeks & $\begin{array}{c}\text { High Fat } \\
21 \%\end{array}$ \\
\hline Qian $^{21}$ & Rats SD & ND & Male & 12 weeks & High Fat \\
\hline $\begin{array}{l}\text { Quiño- } \\
\text { nes }^{22}\end{array}$ & Rats SD & $\begin{array}{c}6 \\
\text { weeks }\end{array}$ & Male & 10 weeks & $\begin{array}{c}\text { High Fat } \\
60 \%, \\
\text { Low Fat } \\
10 \%\end{array}$ \\
\hline $\begin{array}{c}\text { Roberts- } \\
\text { tole }{ }^{23}\end{array}$ & $\begin{array}{c}\text { Mice } \\
\text { C57BL }\end{array}$ & $\begin{array}{c}6 \\
\text { weeks }\end{array}$ & Male & $\begin{array}{l}16-22 \\
\text { weeks }\end{array}$ & $\begin{array}{c}\text { High Fat } \\
60 \%, \\
\text { Hight. } \\
\text { Carb 70\% }\end{array}$ \\
\hline Zhuhua $^{24}$ & $\begin{array}{l}\text { Mice } \\
\text { ICR }\end{array}$ & $\begin{array}{c}8 \\
\text { weeks }\end{array}$ & Male & 12 weeks & $\begin{array}{l}\text { High Fat, } \\
\text { High Carb }\end{array}$ \\
\hline
\end{tabular}

Note: Some studies worked with one or more types of species of animals. ND: non determined.
TABLE 2 - Distribution of variables by categories of scientific articles published on animal models of disease to obesity between the years 2010-2016 $(n=19)$.

\begin{tabular}{cc}
\hline VARIABLE & TOTAL \\
\hline Year of Publication & \\
$2010-2011$ & 05 \\
$2012-2013$ & 03 \\
$2014-2015$ & 11
\end{tabular}

Animal Species

$\begin{array}{ll}\text { Mice } & 10 \\ \text { Rats } & 10\end{array}$

Age of animals

$\begin{array}{cc}21 \text { days } & 02 \\ 4 \text { a } 8 \text { weeks } & 11 \\ \geq 8 \text { weeks } & 02 \\ \text { ND } & 04\end{array}$

Sex of Animals

$\begin{array}{cc}\text { Male } & 16 \\ \text { Female } & 01 \\ \text { Ambos } & 02\end{array}$

Follow-up time

$\begin{array}{cc}6 \text { a } 10 \text { weeks } & 05 \\ 11 \text { a } 16 \text { weeks } & 09 \\ >16 \text { weeks } & 05 \\ \text { Type of diet } & \\ \text { High Fat } & 18 \\ \text { High Carb } & 06\end{array}$

Note: For some variables, the roles worked with more than one animal and diet option. ND: non determined.

\section{Discussion}

A suitable animal model with rodents should allow the study of biological phenomena, animal behavior, induced pathological process or spontaneous. This model should be similar to the human characteristics in several respects. It is from the physiological and genetic similarities between both, that studies in animal models provide the understanding of diseases in humans ${ }^{4}$.

From the animal model it is possible to obtain information faster and better control of the disease such as obesity and its comorbidities. The searches for replies on the physiological dysfunctions in diseases induced by promoted animal model of obesity are increasingly intense. It is observed in the number of papers published in the last 3 years (2013-2015) which was higher for the years 2010-2012 according to this review. 
In the reports evaluated in our review, the use of rat in

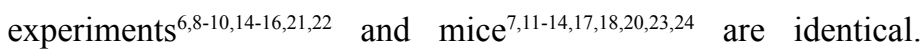
However, in a survey conducted by Fagundes and $\mathrm{Taha}^{25}$ the rats were most used in experimental studies than the mouse. But it notes that the use of mice in the study of obesity has grown in recent years.

The insertion of mice as laboratory animals is due mainly to the size, very prolific, have a short gestation period and easily of taming 5 . Mice require small space for its establishment, and consume a smaller amount of food. Thus their maintenance is cheap compared to the mouse. Mice have little blood volume, which sometimes does not allow the realization of biochemical tests. On the other hand, some researchers choose to use the mouse.

In the most studies the found age range was 4 to 18 weeks. It is interesting to note that the puberty of rat occurs 30 days after his birth and the mice is between 30 to 40 days. The sexual maturation of both occurs around sixty days. Factors such as age and different maturation cycles, and diseases related to the lifetime can interfere in the outcome of research 5 .

Most of the selected works in this review used male animals, probably this preference may be related to own existing biological structure between the sexes ${ }^{6-13,15-24}$. Male have hormonal factors that are related to body growth, which reflected in higher body weight ${ }^{23}$. While these hormones in female are related to the lower growth of body and increased of fat storage ${ }^{26}$. The amount of hormone is related to metabolic alterations such as leptin and adiponectin, it is higher in female, thus influencing in the food and energy intake, as well as weight gain interfering ${ }^{26}$.

Different studies in the literature use C57BL / 6J mice and consider the follow-up time greater than 15 weeks to obesity induced by high fat diet ${ }^{27,28}$. However, in another study with Swiss mice found that it took only about 10 weeks to induce obesity by means of a high-fat diet, in this case with the same percentage of lipids described above ${ }^{29}$.

In our revision, it was found that $47,3 \%$ of the analyzed studies used the follow-up time from 11 to 16 weeks and $26.3 \%$ worked with the follow-up time from 6 to 10 weeks , and $26,3 \%$ have taken follow-up time next greater than 16 weeks. Thus, it was possible to verify the existence of variation of the follow-up times used in the studies. There was a major highlight in studies with follow-up time that exceeded 11 to 16 weeks.

With respect to the diets evaluated in the articles the most representative was Hight Fat using fat sources such as lard oil and soybean, but it considers different concentrations of lipids in the preparation. In diets with ratio of $40 \%$ to $60 \%$ of lipids, obesity induction occurred in all groups, regardless of the strains of rodents ${ }^{6,9-12,15,17,18,22-24}$. In experiments with diets containing $60 \%$ lipids, mice obtained in addition to weight gain and epididymal fat, hyperglycemia and insulin resistance ${ }^{11,12,23}$.

In simple carbohydrate calorie diet (High Carb) with a mean proportion of $60 \%$ based on sucrose, fructose and corn starch, the animals had increased weight, body fat, triglycerides, hyperglycemia and hypertension ${ }^{18}$. In a study with the cafeteria diet (bacon, biscuit, pâté and milk sugar) the levels of triglycerides and glucose were altered and liver was increased ${ }^{16}$.

The effect of diets in rodents has been studied since 1988, showing that feeding high-fat, simple carbohydrates and poor in fiber produce obesity and is associated to moderate intolerance factors glucose, insulin resistance, dysfunction of the islets of Langerhans and type 2 diabetes in rodents. Therefore, the standard HF diet can be used for studies on the mechanisms of obesity and as a tool for the development of new therapeutic interventions ${ }^{29,30}$.

\section{Conclusions}

This literature review indicates that both rats and mice were used in the same proportion in experimental studies in obesity model, were observed variations in age to the beginning of the experiment soon after weaning. The follow-up time of the studies, in general, proved to be long. Furthermore, the High Fat diet was the most used in the studies analyzed. Given the above, this study demonstrates the importance of animal models of disease in the scientific field, in spite of intense ethical discussions on the use of laboratory animals for experimental research.

\section{References}

1. WHO (World Health Organization. Obesity and overweight). 2015. Available in http://www.Who.Int/Mediacentre/Factsheets/Fs311/ En/.

2. Malta, DC, Silva Jr, J B. O plano de ações estratégicas para o enfrentamento das doenças crônicas não transmissíveis no Brasil e a definição das metas globais para o enfrentamento dessas doenças até 2025: uma revisão. Epidemiol Serviços Saúde. 2013;22(1):151-64. doi: 10.5123/S1679-49742013000100016.

3. WHO (World Health Organization). 2000. Obesity: preventing and managing the global epidemic (No. 894). World Health Organization. ISBN: 85-7541015-6.

4. Rossini TC, Silva ASR, Moraes C. Obesidade induzida por consumo de dieta: modelo em roedores para o estudo dos distúrbios relacionados com a obesidade. Rev Assoc Méd Bras. 2012;58(3):383-7. doi: 10.1590/S0104- 42302012000300021.

5. Andrade A, Pinto SC, De Oliveira RS. Animais de laboratório: criação e experimentação. Scielo-Editora FIOCRUZ, 2006. ISBN: 85-7541-015-6.

6. Bong HY, Kim JY, Jeong HI, Moon MS, Kim J, Kwon O. Effects of corn gluten hydrolyzates, branched chain amino acids, and leucine on body weight reduction in obese rats induced by a high fat diet. Nutr Res Pract. 2010;4(2):106-13. doi: 10.4162/nrp201042106. 
7. Souza CT, Frederico MJ, Da Luz G, Cintra DE, Ropelle ER, Pauli JR, Velloso LA. Acute exercise reduces hepatic glucose production through inhibition of the foxo1/hnf $4 \alpha$ pathway in insulin resistant mice. J Physiol. 2010;588(12):2239-53. doi: 10.1113/ jphysiol.2009.183996.

8. Oliveira Júnior SA, Dal Pai-Silva M, Martinez PF, Lima-Leopoldo AP, Campos DHS, Leopoldo AS, Okoshi MP, Okoshi K, Padovani CR, Cicogna AC. Diet-induced obesity causes metabolic, endocrine and cardiac alterations in spontaneously hypertensive rats. Med Sci Monit. 2010;16:367-73. PMID: 21119569.

9. McDonald SD, Pesarchuk E, Don-Wauchope A, El Zimaity H, Holloway AC. Adverse metabolic effects of a hypercaloric, high-fat diet in rodents precede observable changes in body weight. Nutr Res. 2011;31(9):707-14. doi: 10.1016/j.nutres. 2011.08.009.

10. Privitera GJ, Zavala AR, Sanabria F, Sotak, KL. High fat diet intake during pre and periadolescence impairs learning of a conditioned place preference in adulthood. Behav Brain Funct. 2011;7:21. doi: 10.1186/1744-9081-7-2.

11. Watanabe M, Morimoto K, Houten SM, Kaneko-Iwasaki N, Sugizaki T, Horai Y, Mataki C, Sato H, Murahashi K, Arita E, Schoonjans K, Suzuki T, Itoh H, Auwerx, J. Bile acid binding resin improves metabolic control through the induction of energy expenditure. Plos One. 2012;7(8):e38286. doi: 10.1371/journal.pone.0038286.

12. Calligaris SD, Lecanda M, Solis F, Ezquer M, Gutierrez J, Brandan E, Leiva A, Sobrevia L, Conget P. Mice long-term high-fat diet feeding recapitulates human cardiovascular alterations: an animal model to study the early phases of diabetic cardiomyopathy. Plos One. 2013;8(4):e60931. doi: 10.1371/journal.pone.0060931.

13. Krüger $\mathrm{K}$, Gessner $\mathrm{DK}$, Seimetz $\mathrm{M}$, Banisch J, Ringseis $\mathrm{R}$, Eder K, Mooren FC. Functional and muscular adaptations in an experimental model for isometric strength training in mice. Plos One. 2013;8(11):e79069. doi: 10.1371/journal.pone.0079069.

14. Walewski JL, Ge F, Lobdell H, Levin N, Schwartz GJ, Vasselli JR, Pomp A, Dakin G, Berk PD. Spexin is a novel human peptide that reduces adipocyte uptake of long chain fatty acids and causes weight loss in rodents with diet induced obesity. Obesity. 2014;22(7):164352. doi: 10.1002/oby.20725.

15. Borengasser SJ, Kang P, Faske J, Gomez-Acevedo H, Blackburn ML, Badger TM, Shankar K. High fat diet and in utero exposure to maternal obesity disrupts circadian rhythm and leads to metabolic programming of liver in rat offspring. Plos One. 2014;9(1):e84209. doi: 10.1371/journal.pone.0084209.

16. Lalanza JF, Caimari A, Del Bas JM, Torregrosa D, Cigarroa I, Pallàs M, Capdevila L, Arola L, Escorihuela RM. Effects of a post-weaning cafeteria diet in young rats: metabolic syndrome, reduced activity and low anxiety-like behaviour. Plos One. 2014;9(1):e85049. doi:10.1371/journal.pone.0085049.

17. Shao M, Lu X, Cong W, Xing X, Tan Y, Li Y, Jin S. Multiple low-dose radiation prevents type 2 diabetes-induced renal damage through attenuation of dyslipidemia and insulin resistance and subsequent renal inflammation and oxidative stress. Plos One. 2014;9(3):92574. doi: 10.1371/journal.pone.0092574.

18. Tillman EJ, Morgan DA, Rahmouni K, Swoap SJ. Three months of high-fructose feeding fails to induce excessive weight gain or leptin resistance in mice. Plos One. 2014;9(9):e107206. doi: 10.1371/ journal.pone.0107206.

19. Guan Y, Cheng Y, Yin Y, Duan J, Wei G, Weng Y, Guo C, Zhu Y, Wang Y, Xi M, Wen, A. A novel animal model of impaired glucose tolerance induced by the interaction of vitamin e deficiency and 60co radiation. Biomed Res Int. 2015;2015:457246. doi: $10.1155 / 2015 / 457246$.

20. McPherson NO, Owens JA, Fullston T, Lane M. Preconception diet or exercise intervention in obese fathers normalizes sperm microrna profile and metabolic syndrome in female offspring. Am
J Physiol Endocrinol Metab. 2015;308(9):805-21. doi: 10.1152/ ajpendo.00013.2015.

21. Qian Y, Zhong P, Liang D, Xu Z, Skibba M, Zeng C, Li X, Wei T, $\mathrm{Wu}$ L, Liang, G. A newly designed curcumin analog y20 mitigates cardiac injury via anti-inflammatory and anti-oxidant actions in obese rats. Plos One. 2015;10(3):e0120215. doi: 10.1371/journal. pone.0120215.

22. Quiñones M, Folgueira C, Sánchez-Rebordelo E, Al-Massadi O. Circulating irisin levels are not regulated by nutritional status, obesity, or leptin levels in rodents. Med Inflamm. 2015;501:620919. doi: 10.1155/2015/620919.

23. Roberts Toler C, O'neill BT, Cypess AM. Diet induced obesity causes insulin resistance in mouse brown adipose tissue. Obesity. 2015;23(9):1765-70. doi: 10.1002/oby.21.134.

24. Zhuhua Z, Zhiquan W, Zhen Y, Yixin N, Weiwei Z, Xiaoyong L, Qing S. A novel mice model of metabolic syndrome: the high-fathigh-fructose diet-fed ICR mice. Exp Anim. 2015;64(4)435-42. doi: 10.1538/expanim.14-0086.

25. Fagundes DJ, Taha MO. Modelo animal de doença: critérios de escolha e espécies de animais de uso corrente. Acta Cir Bras. 2004;19(1):59-65. doi: 10.1590/S0102-86502004000100010.

26. Martin LJ, Mahaney MC, Almasy L, Maccluer JW, Blangero J, Jaquish CE. Leptin's sexual dimorphism results from genotype by sex interactions mediated by testosterone. Obesity Res Clin Pract. 2002;10(1):14-21. doi: 10.1038/oby.2002.3.

27. Bose M, Lambert JD, Ju J, Reuhl KR, Shapses SA, Yang CS. The major green tea polyphenol,(-)-epigallocatechin-3-gallate, inhibits obesity, metabolic syndrome, and fatty liver disease in high-fat-fed mice. J Nutr. 2008;138(9):1677-83. PMID: 18716169.

28. Gallou-Kabani C, Vigé A, Gross MS, Boileau C, Rabes JP, FruchartNajib J, Jais JP, Junien C. Resistance to high-fat diet in the female progeny of obese mice fed a control diet during the periconceptual, gestation, and lactation periods. Am J Physiol Endocrinol Metab. 2007;292(4):1095-1100. doi: 10.1152/ajpendo.00390.2006.

29. White SA, Cercato LM, Araújo JMD, Souza LA, Soares AF, Barbosa, Neto JMR, Marça AC, Machado UF, Camargo EA, Santos MRV, Brito LC. Modelo de obesidade induzida por dieta hiperlipidica e associada à resistência à ação da insulina e intolerância a glicose. Arq Bras Endocrinol Metab. 2013;57(5):339-45. doi: 10.1590/ S0004-27302013005500002.

30. Surwit RS, Kuhn CM, Cochrane C, Mccubbin JA, Feinglos MN. Diet-induced type II diabetes in C57BL/6J mice. Diabetes. 1988;37(9):1163-7. doi: 10.2337/diab.37.9.1163.

\section{Correspondence:}

Melina Ribeiro Fernandes

Rua Cora Coralina, 153/02

79040-510 Campo Grande - MS Brasil

Tel.: (55 67)99226-7227

fernandesrmelina@gmail.com

Received: Aug 12, 2016

Review: Oct 14, 2016

Accepted: Nov 14, 2016

Conflict of interest: none

Financial source: none

${ }^{1}$ Research performed at Postgraduate Program in Health and Development, Midwest Region, Universidade Federal do Mato Grosso do Sul (UFMS), Campo Grande-MS, Brazil. 